\title{
KEMAMPUAN MEMBACA AL-QUR'AN BAGISISWA SMP DAN FAKTOR-FAKTOR YANG MEMPENGARUHINYA
}

\author{
(STUDI KASUS SMPN 1, SMPN 4, DAN SMPN 5 KABUPATEN \\ BONE)
}

\author{
Oleh: Ramlah Hakim
}

\begin{abstract}
This research was conducted in Bone, South Sulawesi, especially at SMPN 1, SMPN 4, and SMPN 5 Bone. This research aims to describe the student ability on reading ATQur'an and factors influence that ability. This uses quantitative method, where data was collected by questioner. Then, data was analyzed by statistical analysis.

This research indicates that ability degree on reading Al-Qur'an of those students is commonly good enough. Their mean scores are 80.7 to 86.9. SMPN 5 get the highest score (86.9), SMPN 1 get the middle score (86.4), and SMPN 4 get the lowest score (80.7). The factor that significantly influence that students ability is the method in reading (and writing) Al-Qur'an.
\end{abstract}

Key words: ability, reading, Al-Qur'an, student

\section{PENDAHULUAN}

$\mathrm{M}$

asyarakat Sulawesi Selatan dikenal sebagai masyarakat yang'memiliki tradisi keagamaan yang sangat kuat. Relasi antara adat $\left(a d e^{\prime}\right)$ dan syariat agama $\left(s a r a^{\prime}\right)$ sangat berpengaruh dalam perjalanan sejarah masyarakat Sulawesi Selatan. Adat melandasi syariat dan syariat melandasi adat. Hal inilah yang kemudian menyebabkan Islam tidak dianggap sebagai agama yang diimpor dari negara lain, tetapi dianggap sebagai agama yang muncul 


\section{Ramlah Hakim}

dari tanah Sulawesi Selatan. Ini disebabkan oleh proses adaptasi Islam yang sangat romantis dan tidak merusak identitas masyarakat Sulawesi Selatan (terdiri dari kerajaan Gowa, Bone, Ajatappareng, Massenrempulu, Luwu dan Iain-lain) saat itu.

Sebagai implementasi dari kuatnya tradisi keislaman tersebut adalah kenyataan yang menunjukkan bahwa masyarakat Sulawesi Selatan merasa sangat bersalah jika anak-anak mereka tidak mampu membaca Alquran. Karena itulah, sejak zaman dahulu hingga saat ini, terutama di pedesaan kita masih dapat menemukan individu-individu atau komunitas-komunitas pengajian yang bertugas untuk mengajarkan Alquran kepada anak-anak usia sekolah meski tidak mendapatkan gaji. Pekerjaan sebagai guru ngaji sendiri bagi mereka adalah sebuah kebanggaan.

Pergulatan masyarakat Sulawesi Selatan dengan modernitas membawa banyak perubahan terhadap pola minat generasi muda terhadap budaya membaca Alquran. Perubahan pilihan-pilihan hidup masyarakat yang berorientasi pada kehidupan modern itu berdampak pada menurunnya minat generasi muda untuk mempelajari dan (atau sekedar) membaca Alquran. Akibatnya, banyak di antara generasi muda yang tidak tahu baca tulis Alquran.

Menyadari hal tersebut, pemerintah daerah Sulawesi Selatan sejak sepuluh tahun terakhir mencanangkan program buta aksara Alquran sebagai salah program keagamaan yang dianggap strategis. Hanya saja, hasil monitoring dan evaluasi Tim Pemantau Gerakan Pembelajaran Alquran se-Provinsi Sulawesi Selatan pada tahun 2004 menemukan bahwa secara umum gerakan Pembelajaran Alquran di Sulawesi Selatan belum berjalan secara efektif. Hal inilah kemudian yang melatari Balai Litbang Agama merasa perlu untuk melakukan penelitian tentang kemampuan membaca Alquran dengan sasaran siswa SMP di berbagai kota di Sulawesi Selatan.

Berdasarkan latar belakang di atas, maka penelitian tentang kemampuan membaca Alquran siswa SMP mengangkat suatu permasalahan, yaitu : bagaimana tingkat kemampuan membaca Alquran siswa SMP? Dan faktorfaktor apa yang mempengaruhi tingkat kemampuan tersebut?

Tujuan penelitian ini adalah untuk menggambarkan tingkat kemampuan dan faktor-faktor yang mempengaruhi tingkat kemampuan tersebut pada siswa SMP (khususnya SMPN 1, SMPN 4, DAN SMPN 5 KABUPATEN BONE) dalam membaca Alquran. 
Manfaat yang diharapkan dari hasil penelitian ini adalah pemerintah memperoleh bahan masukan untuk membuat kebijakan khususnya mengenai pemberantasan buta aksara Alquran. Secara akademis, hasil penelitian ini diharapkan menjadi bahan rujukan bagi penelitian dan kajian-kajian lain yang berkaitan dengan kemampuan membaca Alquran.

\section{METODE PENELITIAN}

Penelitian ini menggunakan penelitian kuantitatif. Lokasi penelitian dilakukan di Kabupaten Bone, tepatnya di SMPN 1, SMPN 4, dan SMPN 5 Kabupaten Bone. Penentuan lokasi sekolah dilakukan berdasarkan kriteria sekolah favorit, sekolah biasa, dan sekolah yang dianggap kurang baik mutunya. Penetapan kriteria ini juga didasarkan pada penilaian umum yang berlaku di Kabupaten Bone.

Informal! dalam penelitian ini adalah seluruh siswa di ketiga SMPN di atas sebagai populasi, dengan sampel kelas 2 di masing-masing sekolah. Penetapan informan dilakukan secara acak dengan meminta bantuan kepada pihak-pihak sekolah.

Analisis data digunakan dengan pendekatan analisis statistik. Statistik deskriptif digunakan untuk menggambarkan data tentang tingkat kemampuan membaca Alquran para siswa. Statitistik inferensial digunakan untuk menganalisa faktor yang berpengaruh terhadap kemampuan siswa.

Penelitian ini dilakukan di Kabupaten Bone Provinsi Sulawesi Selatan. Penelitian difokuskan pada Sekolah Menengah Pertama Negeri sebanyak 3 (tiga) buah, yaitu SMP Negeri 1 sebagai ketegori unggulan, sebanyak 40 responden, SMP Negeri 4, kategori sedang sebanyak 39 responden dan SMP Negeri 5 Bone sebagai sekolah yang berstatus kurang dengan jumlah responden sebanyak 37 orang.

\section{PEMBAHASAN}

1. Gambaran Umum Kemampuan Membaca Alquran pada Siswa SMPN 1, SMPN 4, dan SMPN 5 Kabupaten Bone

Hasil tes prosentase membaca Alquran dengan menjumlahkan skor setiap dimensi dari setiap responden kemudian dikategorikan menjadi empat tingkatan kemampuan membaca berdasarkan data teoritik kemampuan membaca Alquran dihitung nilai rentangan hingga memperoleh penilian kurang yaitu 0 sampai dengan 
37-38 sampai dengan 65 penilaian sedang 66 sampai dengan 92 dengan penilaian baik dan 93-110 adalah penilaian sangat baik. Berdasarkan pada tiap-tiap skor, maka nilai dikategorikan skor 1 (peretama) adalah kemampuan membaca Alquran kurang (0-37), skor 2 (kedua) kemampuan membaca Alquran sedang ( 38-65) skor 3 (ketiga) adalah kemampuan membaca Alquran baik (66-92) sedangkan untuk skor 4 (keempat) adalah kemampuan membaca Alquran sangat Baik (93-110).

\section{Tabel 1}

Tingkat Kemampuan Membaca Alquran pada 3 SMPN di Kab. Bone

\begin{tabular}{|r|l|r|r|r|r|r|r|r|}
\hline No & $\begin{array}{c}\text { Kelompok Siswa } \\
\text { (SMP) }\end{array}$ & $\begin{array}{c}\text { Nilai } \\
\text { Total }\end{array}$ & Kurang & Sedang & Baik & $\begin{array}{c}\text { Sangat } \\
\text { Baik }\end{array}$ & Jumlah & $\begin{array}{c}\text { Nilai } \\
\text { Rata-rata }\end{array}$ \\
\hline & & & & & & & & \\
\hline 1 & SMPN. 1 Bone & 3387 & & & 37 & 3 & 40 & 84,675 \\
\hline 2 & SMPN.4Bone & 3149 & & 6 & 27 & 6 & 39 & 80,7439 \\
\hline 3 & SMPN.5Bone & 3218 & & 1 & 24 & 12 & 37 & 86,97297 \\
\hline & Jumlah & & & 7 & 89 & 20 & 116 & \\
\hline
\end{tabular}

Tabel di atas menujukkkan bahwa dari ketiga sekolah yang dijadikan sampel SMPN 5 memperoleh tingkat membaca Alquran yang paling tinggi dengan nilai rata-rata (mean scoure) 86,97297 dengan jumlah responden kurang dibanding dua sekolah lainnya.

2. Gambaran Umum Uji Kemampuan dengan 5 (lima) Kategori Tes Kemampuan terhadap 3 SMPN di Bone; N: 116 orang

Tabel 2.

Gambaran Umum Setelah Uji Kemampuan dengan 5 (lima)

Kategori Tes maka diperoleh Tingkat Kemampuan

Sesuai dengan uraian terdahulu, bahwa instrumen tes kemampuan baca Alquran untuk kelas II SMP meliputi tiga indikator dan ini ditemukan pada surah At-Tiin, karena itu kemampuan yang dituntut dalam standar kompetensi tersebut adalah kemampuan membaca surah At-Tiin. Atas dasar itu, maka disusun instrumen dengan empat ketegori: 


\begin{tabular}{|l|c|c|c|c|}
\hline Jenis Kemampuan & $\begin{array}{c}\text { SMPN 1 Bone } \\
\text { (Unggulan) }\end{array}$ & $\begin{array}{c}\text { SMPN 4 Bone } \\
\text { (Menengah) }\end{array}$ & $\begin{array}{c}\text { SMPN 5Bone } \\
\text { (Kurang) }\end{array}$ & Ket \\
\hline $\begin{array}{l}\text { A. Kemampuan Mengenal } \\
\text { dan menyebut huruf } \\
\text { qalqalah }\end{array}$ & 20.8 & 29,3 & 29,8 & \\
$\begin{array}{l}\text { B. Kemampuan membaca } \\
\text { kata-kata }\end{array}$ & 16 & 14,9 & 32,3 & \\
$\begin{array}{l}\text { C. Kemampuan membaca } \\
\text { potongan ayat dengan } \\
\text { tajwid }\end{array}$ & 31,8 & 29,7 & 8,32 & \\
D. Membaca surah At-Tiin & 8,45 & 7,64 & \\
\hline
\end{tabular}

Tabel 2 menujukkan adanya perbedaan tingkat kemampuan yang dimiliki oleh responden SMPN 1, SMPN 4, dan SMPN 5 Bone, setelah uji 4 (empat) kategori yakni bahwa pada tingkat kemampuan mengenal huruf, SMPN 5 memperoleh kemampuan yang lebih tinggi dibanding SMPN 1 dan SMPN 4. Pada kategori kemampuan membaca kata-kata, SMPN 1 memperoleh kemampuan yang sama dengan SMPN 5 dan SMPN 4 paling rendah. Selanjutnya pada ketegori kemampuan membaca ayat dengan tajwid SMPN 5 memperoleh tingkat kemampuan yang lebih tinggi, menyusul SMPN1 dan SMPN 4. Sedangkan pada kategori terakhir yakni kemapuan membaca surah At-Tiin SMPN 1 lebih tinggi menyusul SMPN 5 dan SMPN 4. 
3. Analisis Inferensial Sistem Anova Terhadap Faktor yang Mempengaruhi Kemampuan Membaca Alquran terhadap N: 116 Responden

Tabel. 3

Analisis Faktor yang Mempengaruhi Tingkat Kemampuan

Membaca Alquran pada 3 SMPN N: 116 Responden

\begin{tabular}{|l|c|c|l|}
\hline Faktor yang Mempengaruhi & AMining & F Kritik & Keterangan \\
\hline 1. Pendidikan sebelum SMP & 0,458332 & 2,685643 & Tidak signifikan \\
2. Perbedaan usia & 1,129002 & 2,685643 & Tidak signifikan \\
3. Tempat belajar & 1.129002 & 2.685643 & Tidak signifikan \\
4. Guru yang mengajar & 0,266892 & 2,685643 & Tidak signifikan \\
5. Buku yang digunakan & - & - & - \\
6. Me tod e yang digunakan & 1,246562 & 2,685643 & Signifikan \\
7. Motivasi belajar & 4,40816 & 2,685643 & Tidak signifikan \\
8. Lama belajar & 0,123623 & 2,685643 & Tidak signifikan \\
9. Kendala membaca & 0,543528 & 2,296868 & Tidak signifikan \\
10. Keinginan belajar & 0,823294 & 2,685643 & Tidak signifikan \\
11. Peradaan mudah membaca & 0,995575 & 2,685643 & Tidak signifikan \\
12. Kejelasan pendengaran & 0,284808 & 2,685643 & Tidak signifikan \\
13. Kejelasan penglihatan & $1,190.167$ & 2,685643 & Tidak signifikan \\
14. Kesempurnaan ucapan & 1,520598 & 2,685643 & Tidak signifikan \\
15. Sikap terhadap hukuman & 1,8722382 & 2,685643 & Tidak signifikan \\
\multicolumn{2}{|l|}{} & & \\
\hline
\end{tabular}

Tabel tersebut di atas menunjukkan bahwa adanya tingkat kemampuan membaca Alquran terhadap responden yang dijadikan sampel penelitian ternyata tidak dipengaruhi oleh faktor-faktor seperti yang disebutkan di atas. Kesluruh faktor kecenderungan lebih pada tidak adanya pengaruh yang signifikan terhadap peningkatan kemampuan belajar membaca Alquran. Dari 15 faktor yang mempengaruhi hanya ditemukan satu faktor yang signifikan dan berpengaruh yakni faktor motivasi.

\section{PENUTUP}

\section{A. KESIMPULAN}

Setelah mengadakan uji tes terhadap 3 (tiga ) sekolah menengah pertama negeri yang dijadikan sampel dalam penelitian kemampuan membaca Alquran maka diperoleh hasil tingkat kemampuan membaca Alquran. Adapun kesimpulan dari hasil penelitian tersebut adalah sebagai berikut: 
1. Setelah mengadakan uji tes dengan jumlah pertanyaan sebanyak 13, maka ditemukan tingkat kemampuan masing-masing dari sekolah tersebut yakni bahwa SMPN 1 dengan jumlah responden 40 orang mendapat nilai ratarata (mean scoure) yakni 84,675, SMPN 4 dengan jumlah responden 39 orang memporoleh nilai rata-rata (mean scoure) 80,7439 sedang SMPN 5 dengan jumlah responden memperoleh nilai rata-rata (mean scoure) 86,97297. Dari ketiga sekolah tersebut maka dapat dinyatakan bahwa SMPN 5 sebagai kategori sekolah yang berstatus rendah nampaknya dalam pembelajaran PAI khusus mengenai kemampuan membaca Alquran justru memperoleh nilai yang tinggi dibanding dua sekolah lainnya yakni SMPN1 (unggulan) dan SMPN 4 (menengah)

2. Adanya tingkat kemampuan membaca Alquran terhadap sejumlah responden yang telah dilakukan uji tes, nampaknya faktor yang diduga mempengaruhi tingkat kemampuan membaca Alquran nampaknya tidak memiliki pengaruh dari ke 15 (lima faktor) yang diduga berpengaruh hanya satu faktor yang signifikan yang motivasi belajar Alquran. Sedang 14 faktor yang lain dari analisis anova ditemukan bahwa tidak berpengaruh secara signifikan terhadap kemampuan membaca Alquran bagi setiap responden. 
Ramlah Hakim

\section{DAFTAR PUSTAKA}

Departemen Pendidikan Nasional. 2004. Standar Kompetensi Sekolah Menengah Pertama dan Madrasah Tsanawiyah Kuriklum 2004. Jakarta.

Human A'sad. 1990. Baku Iqra' :Cara Cepat Belajar membaca Alquran. AMM. Yogyakarta.

Shihab, M. Quraish. 1416 H/1996 M. "Membumikan Alquran "Fungsi dan Peranan Wahyu Dalam Kehidupan Masyarakat. Cet. XII. Mizan. Bandung.

Sulthan Muhajirin. 1999. Buku Belajar Mengaji Al-Barqy, Secepat Kilat Penasuci. Surabaya.

Laboran. 1993. Studi Eksperimentasi Metode Baca Tulis Alquran pada Sekolah Dasar.

Laporan. 2004. Hasil Pemantauan dan Evaluasi " Gerakan Pembelajaran Alquran (GPQ) Provinsi Sulawesi Selatan. 